Article

\title{
On the Effects of Variation of Thermal Conductivity in Buildings in the Italian Construction Sector
}

\author{
Umberto Berardi ${ }^{1}\left(\mathbb{D}\right.$, Lamberto Tronchin $^{2, *} *$ (D), Massimiliano Manfren ${ }^{3}$ \\ and Benedetto Nastasi 4 (iD) \\ 1 Department of Architectural Science, Ryerson University, 350 Victoria Street, Toronto, ON M5B2K3, Canada; \\ uberardi@ryerson.ca \\ 2 Department of Architecture (DA), University of Bologna, Viale Europa 596, 47521 Cesena, Italy \\ 3 Faculty of Engineering and the Environment, University of Southampton, Highfield, \\ Southampton SO17 1BJ, UK; M.Manfren@soton.ac.uk \\ 4 Department of Architectural Engineering \& Technology, TU Delft University of Technology, Julianalaan 134, \\ 2628BL Delft, The Netherlands; benedetto.nastasi@outlook.com \\ * Correspondence: lamberto.tronchin@unibo.it; Tel.: +39-051-2090542
}

Received: 10 February 2018; Accepted: 5 April 2018; Published: 9 April 2018

check for updates

\begin{abstract}
Stationary and dynamic heat and mass transfer analyses of building components are an essential part of energy efficient design of new and retrofitted buildings. Generally, a single constant thermal conductivity value is assumed for each material layer in construction components. However, the variability of thermal conductivity may depend on many factors; temperature and moisture content are among the most relevant ones. A linear temperature dependence of thermal conductivity has been found experimentally for materials made of inorganic fibers such as rockwool or fiberglass, showing lower thermal conductivities at lower temperatures. On the contrary, a nonlinear temperature dependence has been found for foamed insulation materials like polyisocyanurate, with a significant deviation from linear behavior. For this reason, thermal conductivity assumptions used in thermal calculations of construction components and in whole-building performance simulations have to be critically questioned. This study aims to evaluate how temperature affects thermal conductivity of materials in building components such as exterior walls and flat roofs in different climate conditions. Therefore, experimental conductivities measured for four common insulation materials have been used as a basis to simulate the behavior of typical construction components in three different Italian climate conditions, corresponding to the cities of Turin, Rome, and Palermo.
\end{abstract}

Keywords: insulation materials; thermal conductivity; building energy consumption; temperature dependence; high-performance buildings

\section{Introduction}

In 2010, buildings accounted for 32\% of total global final energy use, 19\% of energy-related Greenhouse Gas (GHG) emissions, 51\% of global electricity consumption, 33\% of carbon emissions, and an eighth to a third of F-gases emissions [1]. In residential buildings, space heating shows the highest share of total primary energy consumption, equal to $32 \%$. In commercial buildings as well, space heating dominated consumption with a $33 \%$ share of the total primary energy consumption [1]. In the European Union (EU), important efforts have been put into energy policies and different directives have resulted in recent years. Among them, the most important ones are the Energy Performance of Buildings Directive [2,3] and the Energy Efficiency Directive [4]. Further, there is much evidence that improving energy efficiency practices in the existing building stock will be crucial for energy sustainability at the EU level [5]. This strategy is even defined as the "new start" for the 
new EU economy [6] since the finance of energy efficiency can be unlocked by public and private partnership and not rely only on EU funds [7]. Considering the problem of space heating demand reduction, heat losses can be decreased by improving envelope performance with increased levels of insulation. This measure is the most effective way to drastically reduce heating demand, considering, of course, dependence on climate conditions [8]. However, in the existing building stock, this measure is much more costly than the replacement of boilers in heating systems $[9,10]$. Nonetheless, there are evident synergies between building envelope performance enhancement and sizing and operation of technical systems [11], even in the case of advanced energy conversion systems [12]. Following this evidence, many research efforts have been concentrated on the definition of methodologies [13] for the determination of cost-optimal levels of energy performance [13] in new and retrofitted buildings [14,15], and the impact of insulation can be extremely relevant in modelling [16]. Clearly, a reasonably robust performance estimate [17] is necessary to evaluate project feasibility. In this sense, uncertainty of energy performance represents an issue in techno-economic assessment methodologies and relevant sources of uncertainty have to be considered to limit as much as possible the "performance gap" [18], or side effects such as "re-bound" [19], "pre-bound" [20], and overheating risk [21]. These effects could potentially undermine the credibility of energy efficiency practices and, for these reasons, appropriate methodological tools are needed to account for uncertainty in building applications-for example, at the energy performance contracting level [22].

This paper focuses on one particular aspect that may affect the performance of building insulation materials (and, consequently, overall building performance) - temperature dependence of thermal conductivity-and how the approximations used in calculation tools may affect performance estimates. So far, this aspect is normally neglected and has not been considered in a number of scientific publications about energy behavior of buildings. In particular, the potential uncertainty introduced by constant and linear temperature dependence approximations is addressed by combining experimental analysis and thermohygrometric simulations for selected case studies in three Italian climate conditions.

\section{Impact of Thermal Insulation Variability in Building Energy Performance}

In common design practice, the starting point for building energy performance analysis is the thermal analysis of building construction components and fabric. A more accurate analysis requires the use of thermohygrometric modelling tools, based on heat, air, and moisture transfer (HAMT) algorithms [23]. This type of analysis is not generally integrated into energy simulation and is conducted in a separate way according to specific standards [24], considered for building code compliance checking.

Heat transfer in building components occurs through three modes: conduction, convection, and radiation [25]. In dynamic building energy modelling tools, monodimensional heat transfer and zonal energy and mass balances are generally considered [26,27]. For these reasons, several approximations are introduced in the modelling process. These approximations will be briefly summarized hereafter, showing the impact of thermal conductivity at multiple scales of analysis:

1. $\quad$ single layers of material;

2. construction components;

3. overall building fabric.

First, the thermal conductivity concept was introduced by Fourier with his phenomenological law of heat [11]. This law states that heat transfer rate through a material is proportional to the negative temperature gradient and to the area through which heat flows. By considering a monodimensional heat transfer problem through a single material layer in stationary conditions, we can write

$$
\begin{gathered}
q=-\frac{\lambda}{s}\left(\theta_{e}-\theta_{i}\right) A \\
Q=\frac{\lambda}{s}\left(\theta_{i}-\theta_{e}\right) A \Delta t
\end{gathered}
$$


where

$q$ is heat transfer rate;

$Q$ is thermal energy transfer;

$\lambda$ is thermal conductivity;

$s$ is depth of the material layer;

$A$ is area;

$\Delta t$ is time interval;

$\theta_{i}$ is internal side temperature;

$\theta_{e}$ is external side temperature.

Building construction components generally constitute multiple layers of material and we can account for stationary heat transfer by introducing thermal transmittance $U$ [28]. Limits on $U$ (or $R$ ) values of individual construction components are generally imposed by building regulations. Convective and radiative heat transfer taking place respectively on the internal and external surfaces of components are accounted for by specific resistances in the calculation [28]. The stationary thermal energy transfer for a multilayered construction component can be calculated as follows:

$$
\begin{gathered}
U=\frac{1}{R}=\frac{1}{\left(R_{s i}+\sum_{i} \frac{s_{i}}{\lambda_{i}}+R_{s e}\right)}=\frac{1}{\left(\frac{1}{h_{s i}}+\sum_{j} \frac{s_{i}}{\lambda_{i}}+\frac{1}{h_{s e}}\right)} \\
Q=U A\left(\theta_{e}-\theta_{i}\right) \Delta t
\end{gathered}
$$

where

$U$ is thermal transmittance;

$R$ is thermal resistance;

$\lambda_{i}$ is thermal conductivity of layer $i$;

$s_{i}$ is depth of material layer $i$;

$R_{s i}$ is thermal resistance on internal side;

$R_{s e}$ is thermal resistance on external side;

$h_{i}$ is thermal heat transfer coefficient on internal side, accounting for convection and radiation;

$h_{e}$ is thermal heat transfer coefficient on external side, accounting for convection and radiation;

$Q$ is the thermal energy transfer.

In order to easily account for the overall heat transfer performance of the building fabric in stationary conditions, heat transfer coefficient $H$ can be introduced [29]. Similar to the $U$ value, in building regulations, limits can be set for the overall fabric performance using $H$. The heat transfer coefficient can be calculated as follows:

$$
\begin{gathered}
H_{t r}=\sum_{i} U_{i} \cdot A_{i}+\sum_{j} \psi_{j} \cdot l_{j}+\sum_{k} \chi_{k} \\
Q_{t r}=H_{t r}\left(\theta_{i}-\theta_{e}\right) \Delta t
\end{gathered}
$$

where

$H_{t r}$ is the thermal heat transfer coefficient for the building fabric;

$U_{i}$ is the thermal transmittance of construction component $i$;

$A_{i}$ is the surface area of construction component $i$;

$\psi_{j}$ is the heat transmission coefficient for two-dimensional thermal bridge $j$;

$l_{j}$ is the length of the two-dimensional thermal bridge $j$; 
$\chi_{k}$ is the heat transmission coefficient for three-dimensional thermal bridge $k$;

$H_{t r}$ is the heat transfer coefficient for envelope transmission;

$Q_{t r}$ is the heat transfer of the overall building envelope in stationary conditions.

In Equation (5), quantities are introduced to account for bidimensional and tridimensional heat transfer happening in thermal bridges. Even in this case, simplifications are possible, for example, by performing regression analysis on thermal bridges calculated with detailed bidimensional stationary heat transfer models in multiple conditions [30]. Further, moving from stationary to dynamic behavior of building construction components and fabric [26,27], conceptual models can be introduced [31] to simplify performance assessment [32,33]; however, the estimation of aggregated (lumped) thermal properties has to be considered carefully [34], as the potential advantages themselves depend on the operational strategy adopted in buildings [35].

The impact of insulation materials in building components is determined by the low conductivity value. Consequently, the use of insulation sensibly affects all the aggregated physical properties (i.e., $U$ or $R, H$, but also dynamic parameters) from individual components to the overall building fabric. For this reason, it is very important to give boundaries to assumptions and simplifications introduced in calculations. They depend on the specific context of application, i.e., type of construction technologies, climate conditions, and operation strategies. Further, it is also necessary to synthetically visualize the impact of design choices at multiple scales, from individual components to the whole building fabric [36].

Insulation materials generally used in buildings are characterized by a thermal conductivity lower than $0.10 \mathrm{~W} / \mathrm{mK}$, although the most common insulation materials used in the construction industry have thermal conductivities ranging from 0.03 to $0.05 \mathrm{~W} / \mathrm{mK}$. Further, materials with thermal conductivity values lower than $0.03 \mathrm{~W} / \mathrm{mK}$ are becoming more popular today in building applications.

The way an insulation material resists heat flux depends on the microscopic cells where air or other gaseous substances are locked up. In closed-cell materials, the insulation effect is guaranteed by the fact that air or gas contained in the cells is prevented from moving and, therefore, convective heat transfer is significantly suppressed. For example, cells in plastic foam insulation (e.g., polystyrene and polyurethane) contain fluorocarbon gas instead of air, obtaining lower thermal conductivity than air. A different behavior can be observed for blown foam insulation materials like polyisocyanurate. This kind of insulation generally shows low conductivity values since the blowing agent is locked up within the pores, and this condition permits a lower heat transfer by convection and conduction with respect to air. However, if temperature decreases under the condensation value of the aforementioned agent, condensation occurs in the pores and, subsequently, the thermal conductivity value rises due to the higher conductive property of the liquid phase compared to the gaseous phase of the agent [37].

Therefore, thermal conductivity is not directly linked to the insulation material but it is associated with the thermal resistance of the gas used within the material which determines the theoretical value limit $[25,38]$. As such, conduction properties are heavily influenced by the characteristics of raw material, insulation material density, nature and microscopic structure of the solid component, and moisture content and temperature [38-40].

Although commonly used insulation materials show variations in their thermal conductivity determined by temperature, their physical properties are measured at $23.8^{\circ} \mathrm{C}$, the standard test conditions. However, when insulation materials experience realistic temperature oscillations, their thermal conductivities vary significantly with respect to the values obtained in standard test conditions. This effect will be investigated experimentally and by means of simulations in the following sections.

\section{Research Methodology}

In order to evaluate the effects of temperature-dependent thermal conductivities of insulation material in typical Italian construction components, thermohygrometric models were created and a series of simulations were run in different climatic conditions. Experimentally measured data from 
conductivity tests were used as a basis for these simulations. The hygrothermal modelling tool chosen was Wufi ${ }^{\circledR}$ Pro (Fraunhofer Institut für Bauphysik, Stuttgard, Germany) [23], a well-established and tested software used for both research and design purposes. Wufi is used to simulate heat and moisture transfer in multilayered building components and its calculation engine can account for temperature dependence of thermal conductivity of materials. Simulations are used to assess the impact of temperature-dependent thermal conductivities on external walls and flat roofs, representing typical components used in the Italian construction sector. Four insulation materials were considered for experimental analysis: fiberglass, rockwool, polyisocyanurate (PIR), and extruded polystyrene (XPS). These materials were chosen based on their high market share among the conventional solutions [41].

Three different thermal conductivity profiles were used in the simulations for each insulation material:

1. a constant value based on the value measured at standard temperature, i.e., $23.8^{\circ} \mathrm{C}$;

2. a linear temperature-dependent function;

3. experimental values which represent the temperature-dependent thermal conductivities, measured in the laboratory.

In order to demonstrate the effect of temperature-dependent thermal conductivity, simulations were run in three different Italian climate conditions corresponding to three cities: Turin (northern Italy), Rome (central Italy), and Palermo (southern Italy). According to Köppen climate classification [42], Turin has a humid temperate climate, classified as Cfa, with cold, foggy winters and hot summers; Rome has a warm temperate climate, classified as Csa, with warm winters and hot summers; and Palermo has a semi-arid climate, classified as BSk, with moderately cold winters and hot and dry summers. Figure 1 depicts the average monthly temperature trends.

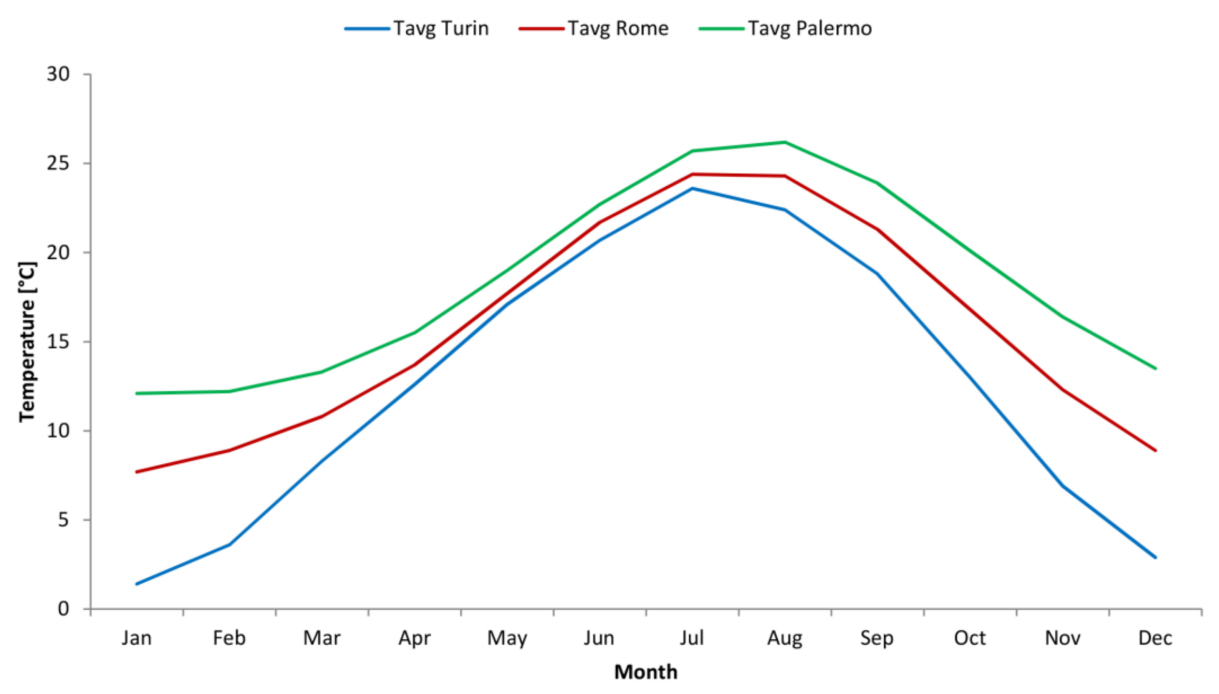

Figure 1. Average monthly temperature (Tavg) trends plotted for Turin, Rome, and Palermo.

In terms of typical construction components, a brick cavity structure for walls and a hollow brick-cement structure for flat roofs were selected for the simulations, as shown in Figure 2. 


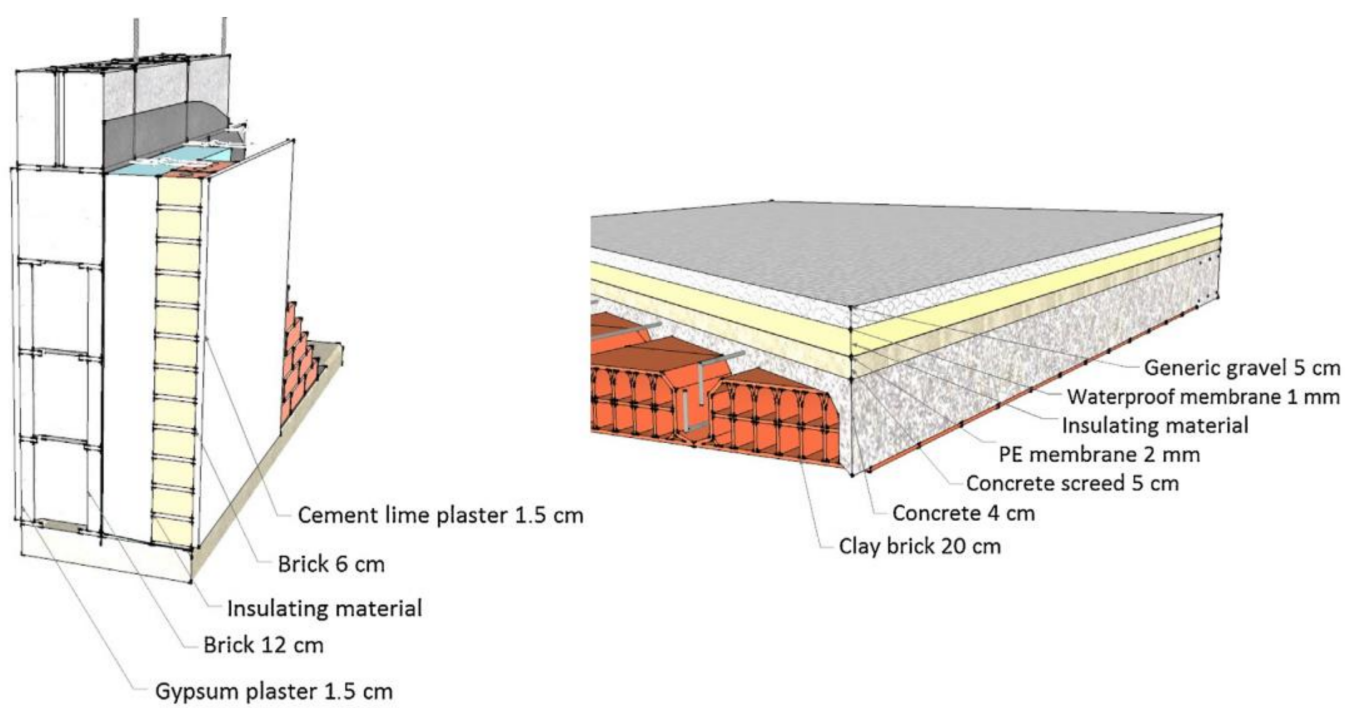

Figure 2. Type of construction components simulated, brick-cavity structure for walls (on the left), hollow brick-cement structure for flat roofs (on the right).

Thermal simulations were run to obtain hourly time-series data of thermal conductivities and heat transfer. In terms of boundary conditions, all the calculations were conducted with $80 \%$ initial relative humidity (RH) and an initial temperature of $20^{\circ} \mathrm{C}$. The initial $\mathrm{RH}$ accounts for materials exposed to the open air before being included in the building envelope. A moisture source was taken into account within the wall assembly for each simulation performed, derived from a percentage $(1 \%)$ of exterior driving rain [43]. In order to account for worst-case conditions, external walls considered were the ones oriented towards the north direction. For each city, a specific maximum $U$-value has been determined for vertical walls and roofs according to current technical standards [28] and Italian national regulations, as reported in Tables 1 and 2. Building indoor temperature was supposed to be constantly $21^{\circ} \mathrm{C}$ in the winter period and $26^{\circ} \mathrm{C}$ in the summer period.

Table 1. Maximum $U$-value data prescribed in Italy used for the selection of the building systems and insulation thickness for constant, linear, and measured conductivities-external walls.

\begin{tabular}{|c|c|c|c|c|c|c|}
\hline \multirow{2}{*}{ Location } & \multirow{2}{*}{$\begin{array}{c}\text { Max } U \text {-Value for } \\
\text { Vertical Wall } \\
\left(\mathrm{W} /\left(\mathrm{m}^{2} \cdot \mathrm{K}\right)\right)\end{array}$} & \multirow{2}{*}{ Typology } & \multicolumn{4}{|c|}{$\begin{array}{l}\text { Insulation Thickness for Constant and Linear } \\
\text { Conductivities/for Measured Conductivities }\end{array}$} \\
\hline & & & $\begin{array}{l}\text { Fiberglass } \\
\quad(\mathrm{cm})\end{array}$ & $\begin{array}{l}\text { Rockwool } \\
(\mathrm{cm})\end{array}$ & PIR (cm) & XPS (cm) \\
\hline Turin & 0.30 & $\begin{array}{c}\text { Wall (brick } \\
\text { cavity structure) }\end{array}$ & $8.0 / 7.5$ & $6.5 / 6.0$ & $5.0 / 5.5$ & $5.5 / 5.0$ \\
\hline Rome & 0.34 & $\begin{array}{c}\text { Wall (brick } \\
\text { cavity structure) }\end{array}$ & $6.0 / 6.0$ & $5.0 / 4.5$ & $4.0 / 4.0$ & $4.5 / 4.0$ \\
\hline Palermo & 0.45 & $\begin{array}{c}\text { Wall (brick } \\
\text { cavity structure) }\end{array}$ & $3.0 / 3.0$ & $2.5 / 2.5$ & $2.0 / 2.0$ & $2.0 / 2.0$ \\
\hline
\end{tabular}

Table 2. Maximum $U$-value data prescribed in Italy used for the selection of the building systems and insulation thickness for constant, linear, and measured conductivities-horizontal roofs.

\begin{tabular}{|c|c|c|c|c|c|}
\hline \multirow{2}{*}{ Location } & \multirow{2}{*}{$\begin{array}{l}\text { Max } U \text {-Value for } \\
\operatorname{Roofs}\left(W /\left(\mathrm{m}^{2} \cdot K\right)\right)\end{array}$} & \multirow{2}{*}{ Typology } & \multicolumn{3}{|c|}{$\begin{array}{l}\text { Insulation Thickness for Constant and Linear } \\
\text { Conductivities/for Measured Conductivities }\end{array}$} \\
\hline & & & $\begin{array}{l}\text { Rockwool } \\
\text { (cm) }\end{array}$ & PIR (cm) & XPS (cm) \\
\hline Turin & 0.25 & $\begin{array}{l}\text { Flat roof (hollow } \\
\text { brick-cement) }\end{array}$ & $8.5 / 8.0$ & $6.5 / 6.5$ & $7.0 / 6.5$ \\
\hline Rome & 0.30 & $\begin{array}{l}\text { Flat roof (hollow } \\
\text { brick-cement) }\end{array}$ & $6.0 / 5.5$ & $4.5 / 5.0$ & $5.0 / 4.5$ \\
\hline Palermo & 0.38 & $\begin{array}{l}\text { Flat roof (hollow } \\
\text { brick-cement) }\end{array}$ & $3.5 / 3.5$ & $2.5 / 3.0$ & $3.0 / 3.0$ \\
\hline
\end{tabular}


Constant and linear temperature-dependent thermal conductivities considered for calculations are reported in Figure 3 for the four insulation materials, in comparison with experimental data. The thermal conductivity of the samples was measured at $23.8^{\circ} \mathrm{C}$ using the heat flow meter apparatus HFM 436/3/1E Lambda produced by Netzsch (Selb, Germany). The apparatus was calibrated with a standard fiberglass board, supplied by the National Institute of Standards and Technology. The measurement accuracy of the apparatus was set to $\pm 1 \%$ (so an error of $\pm 1 \%$ can be expected in the measurement results). Specimens sized with variable thicknesses were placed between the hot and cold plates and the thermal conductivity was measured by the heat flux sensor upon reaching the thermal equilibrium at a defined temperature difference and for a uniform temperature gradient throughout the sample. The sample size was $305 \times 305 \mathrm{~mm}^{2}$, although the heat flow was measured in the central $100 \times 100 \mathrm{~mm}^{2}$ area of the sample. The large sample size compared to the measurement area ensured steady-state thermal conditions for the measuring area so that the surrounding area of the transducer acted as an effective guard against lateral heat flow. To keep track of the moisture content, samples were weighed before and after thermal measurement using a digital scale with $0.1 \mathrm{~g}$ accuracy.

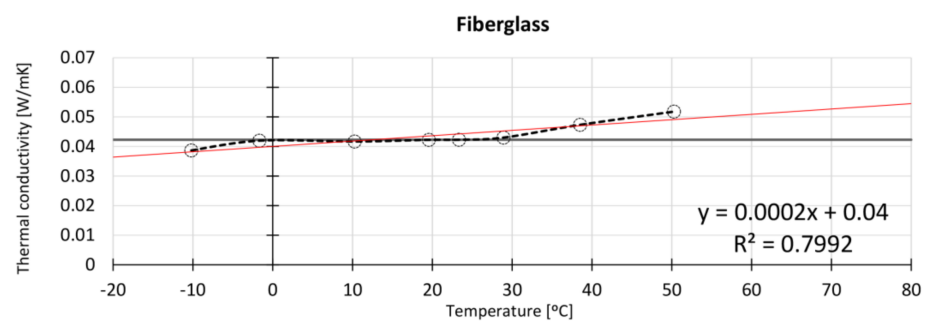

(a)

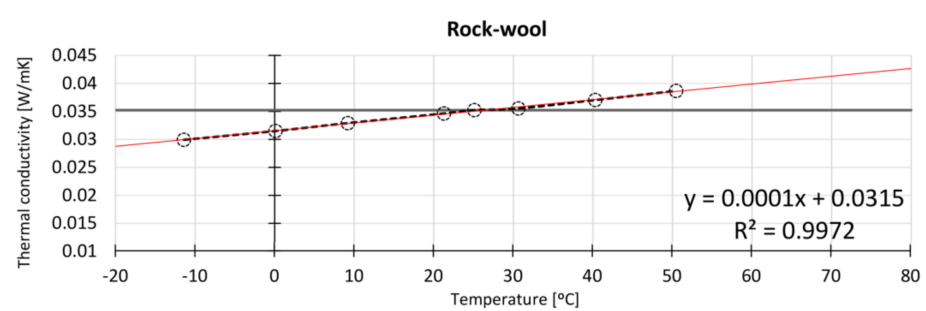

(b)

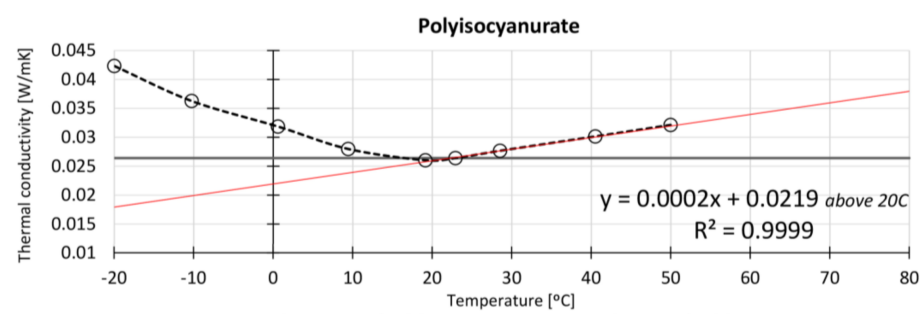

(c)

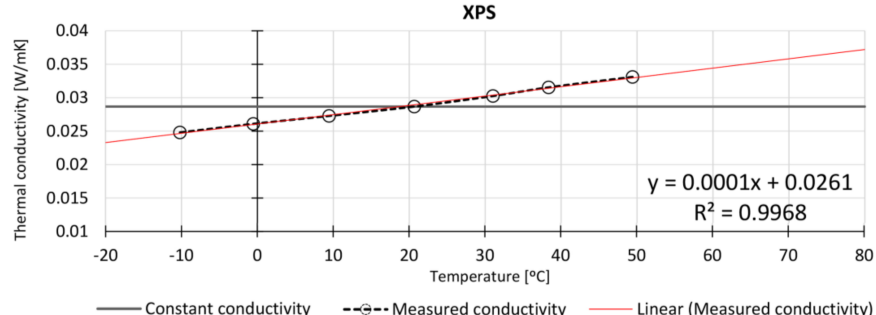

(d)

Figure 3. Temperature dependence of the thermal conductivity for the four analyzed materials, comparing constant, linear, and measured values. (a) Fiberglass; (b) Rockwool; (c) Polyisocyanurate; (d) Extruded polystyrene. 
Conductivities were measured experimentally multiple times in the range from $-20^{\circ} \mathrm{C}$ to $+60^{\circ} \mathrm{C}$ and the final results of the test are reported in Figure 3; data points are between $-10{ }^{\circ} \mathrm{C}$ and $+500^{\circ} \mathrm{C}$ for all materials except for polyisocyanurate, for which the nonlinear behavior is reported up to $-20{ }^{\circ} \mathrm{C}$. The trend lines, supported by the equation reported in the legend, depict the data behavior of materials. It is noteworthy that the thermal conductivity values for rockwool, fiberglass, and extruded polystyrene (XPS) are nearly linear with respect to temperature while polyisocyanurate exhibits a nonlinear behavior with higher conductivity values for colder temperatures. In particular, the deviation from linear behavior begins at $20^{\circ} \mathrm{C}$ and the main change is reached around $10{ }^{\circ} \mathrm{C}$; this is when the blowing agent within the polyisocyanurate microstructure starts condensing, determining the rise of conductivity. This effect has recently been extensively discussed by Berardi and Naldi [44].

\section{Temperature-Dependent Thermal Conductivity in Building Components}

This section concerns the study of variations in thermal conductivity determined by variability of climate conditions. Mid-thickness temperature of the insulation materials has been investigated for the months of January and July, which represent the two extreme conditions, following the methodology described in the previous section for the different locations.

Figures 4 and 5 present the data results for vertical walls and flat roofs, respectively, and are organized by material for each location. The thermal conductivities of exterior walls with fiberglass, rockwool, and extruded polystyrene (XPS) insulation in Figure 4 exhibit better performance at lower temperatures, as shown in the winter time series for Turin and Palermo. They represent the two extreme conditions, Turin corresponding to northern Italy and Palermo to southern Italy. On the contrary, polyisocyanurate (PIR) conductivity increases at lower temperatures with a nonlinear trend. The deviation from linear temperature dependence begins at $20{ }^{\circ} \mathrm{C}$ and the value remains nearly constant up to $10^{\circ} \mathrm{C}$. This fact depends on the gas condensation process inside the polyisocyanurate when temperature falls below $10^{\circ} \mathrm{C}$, as explained before. The case of Rome in winter presents a larger variability because of the combination of low temperatures with high solar radiation that determines larger oscillations.

Fiberglass is not considered for roof insulation because it is not a suitable material for flat roof components. Analyzing the plots relative to flat roofs in Figure 5, we can see how simulations confirm the different behavior of polyisocyanurate with respect to the other insulation materials-rockwool and XPS. What appears to be evident from Figure 1 is the fact that temperatures in Turin are much lower in winter then those in Rome and Palermo and are below $10^{\circ} \mathrm{C}$, the point of condensation of the blowing agent in the polyisocyanurate. Again, Rome in winter presents larger conductivity oscillations because of the combination of low temperatures with high solar radiation. 


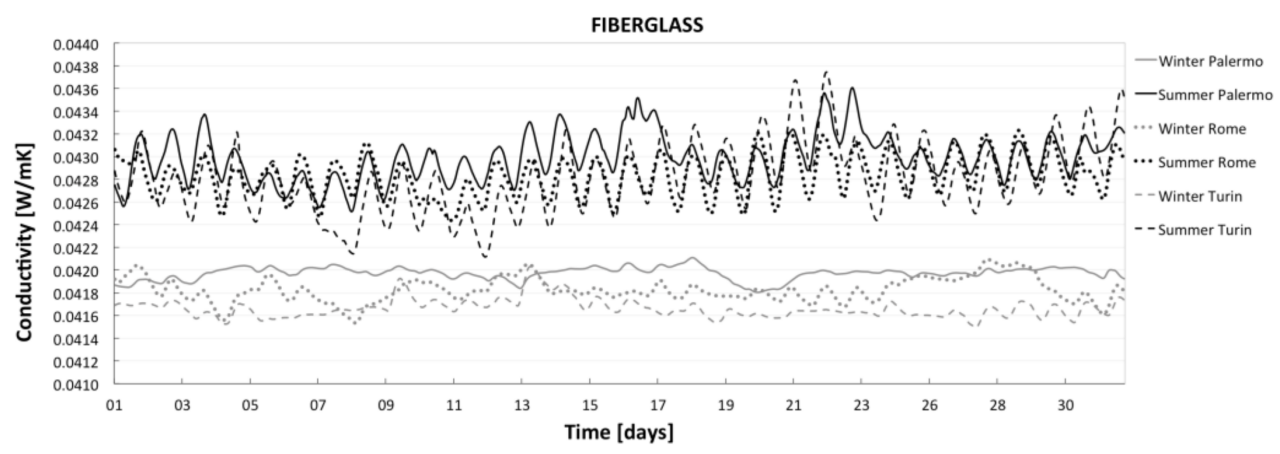

(a)

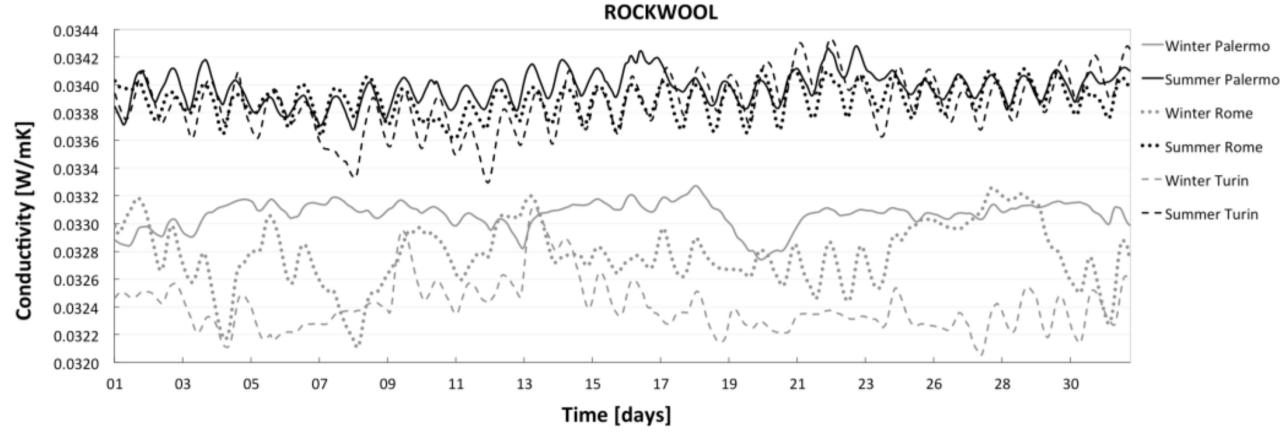

(b)

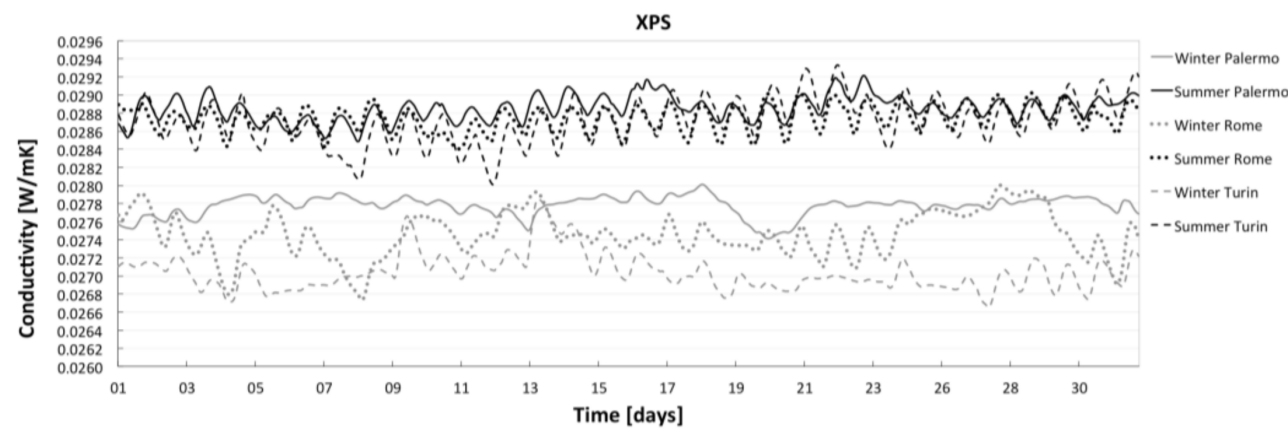

(c)

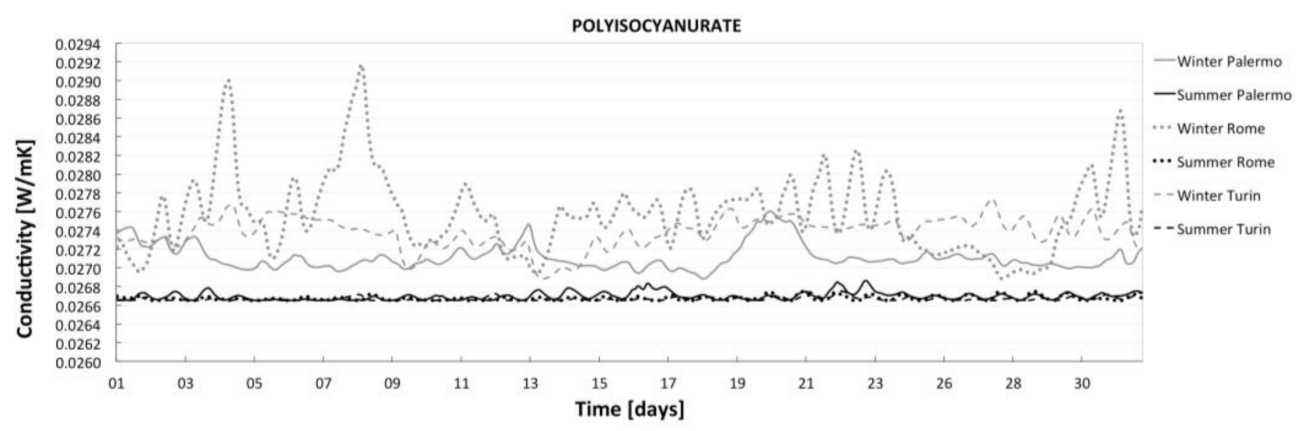

(d)

Figure 4. Time series of thermal conductivity values of insulation materials in external walls. (a) Fiberglass; (b) Rockwool; (c) Extruded polystyrene; (d) Polyisocyanurate. 


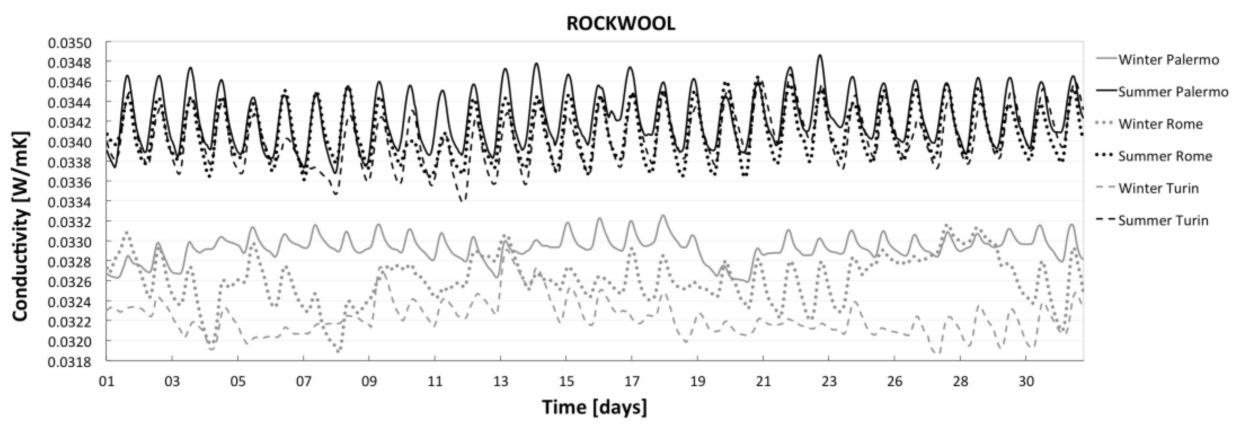

(a)

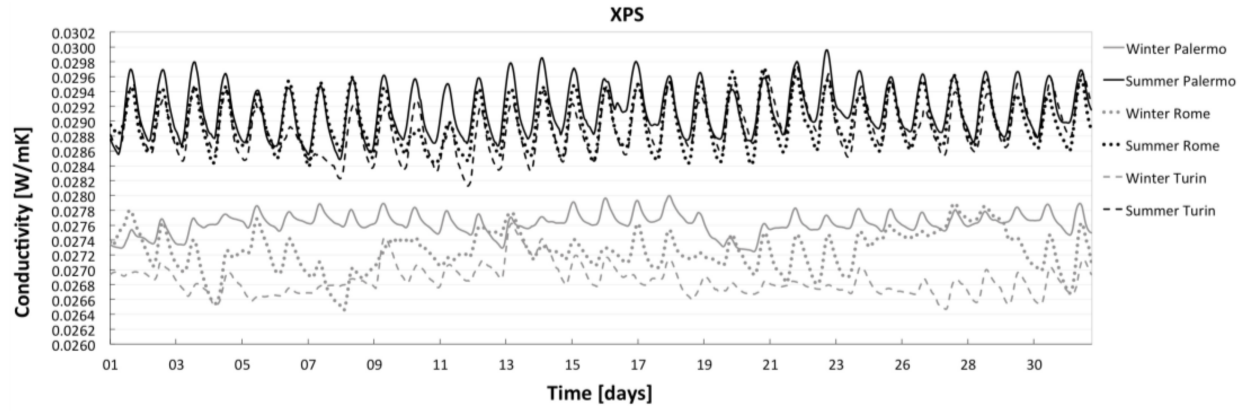

(b)

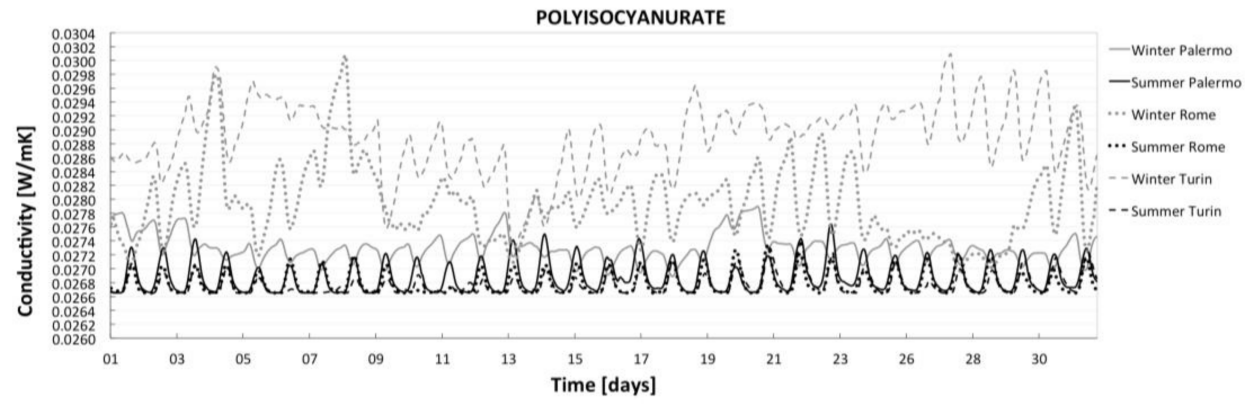

(c)

Figure 5. Time series of thermal conductivity values of insulation materials in flat roofs. (a) Rockwool; (b) Extruded polystyrene; (c) Polyisocyanurate.

\section{Seasonal Average Heat Flux through Building Components}

The definition of normative requirements for building efficiency accounts for climate conditions (and possibly for climate change effects in the medium-long term [45,46]); however, it is difficult to account for complex effects, such as temperature dependency, without using detailed simulation models. Clearly, underestimations or overestimations of building thermal performance have an impact on energy supply design and operation [47]. For this reason, average heat flux values have been analyzed in the subsequent section, comparing percentage deviations.

In order to evaluate how each assumed behavior (in terms of thermal conductivity) for the different materials affects energy consumption in buildings, respective hourly simulated time series of heat losses and gains were analyzed for winter and summer selected periods. The winter period analyzed goes from 1 December to 31 March, while the summer period analyzed goes from 1 June to 30 September. Results for the exterior walls and flat roofs are reported in Figures 6-9 for the two cities Turin and Palermo, representing the two extreme conditions, corresponding respectively to the northern and southern Italian climates. The data presented in Figures 6-9 are average heat fluxes through construction components obtained with the three different assumptions: 
1. constant thermal conductivity;

2. linear temperature dependence of thermal conductivity;

3. experimentally measured thermal conductivity.

Negative values of average heat fluxes represent an average heat loss (heat exiting from thermal zone), while positive values indicate an average heat gain (heat entering thermal zone). As explained in Section 2, the energy balance of construction components depends on its characteristics and on the dynamic conditions of temperature, as well as other effects such as thermal gains due to incident solar radiation. In the case study considered, following Italian normative requirements, the differences between the $U$ values for the components in Turin and Palermo are very large, as reported in Tables 1 and 2.

In the Turin cases, heat fluxes are negative in winter conditions both for external walls and horizontal roofs, while in summer conditions, heat fluxes are negative for external walls and positive for horizontal roofs. In Palermo cases, heat fluxes are negative in winter conditions both for external walls and horizontal roofs, while in summer conditions, heat fluxes are positive both for external walls and horizontal roofs.

The aim of the research in this case was to highlight differences among performance estimates obtained using the different assumptions about thermal conductivity reported previously. In particular, our goal was to show the difference obtained with measured data with respect to constant and linear assumptions. For this reason, Tables 3 and 4 report the percentage difference of average heat fluxes for all the components and locations, comparing

1. experimentally measured with respect to constant thermal conductivity;

2. experimentally measured with respect to linear temperature dependence of thermal conductivity.

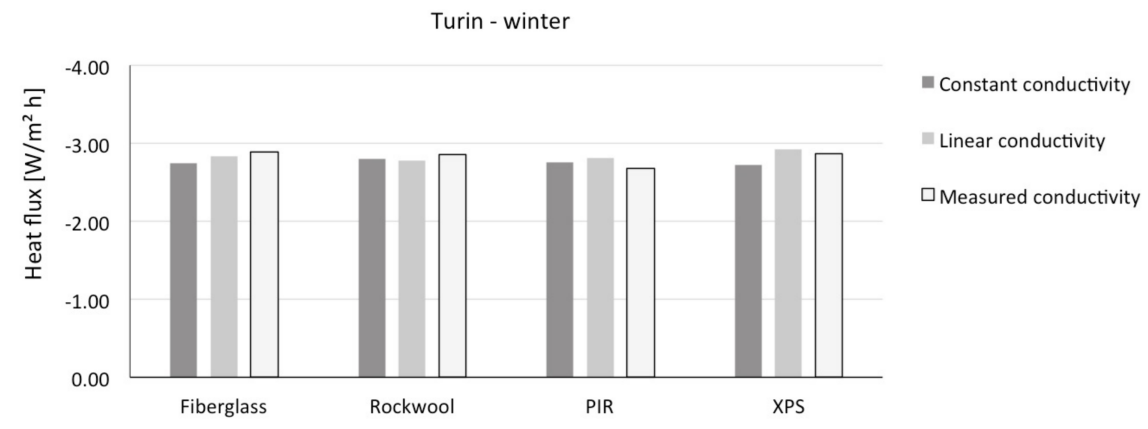

(a)

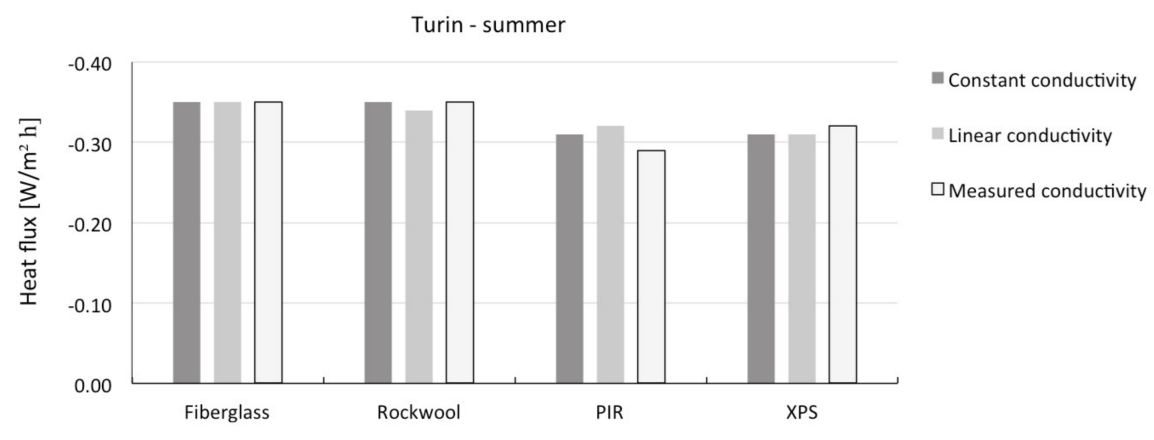

(b)

Figure 6. Heat flux average in exterior walls in Turin. (a) Turin-winter; (b) Turin-summer. 


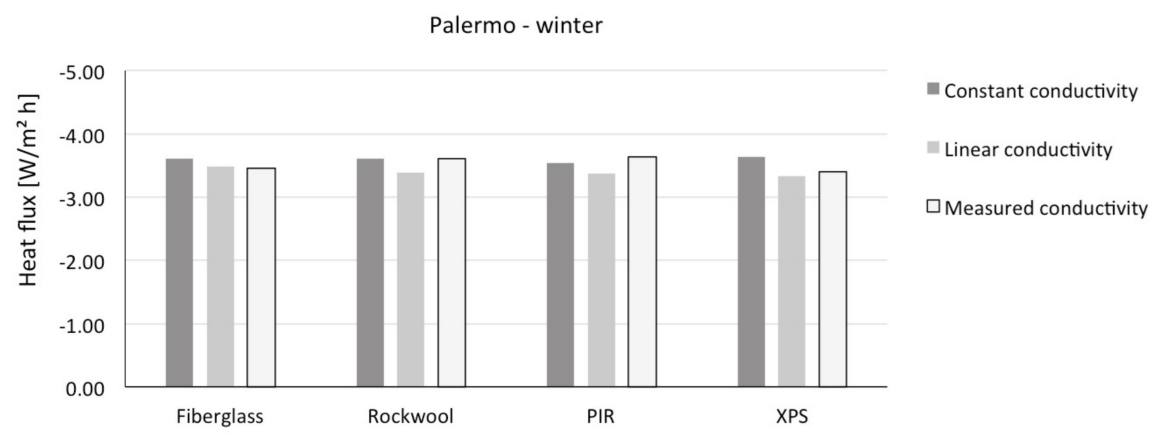

(a)

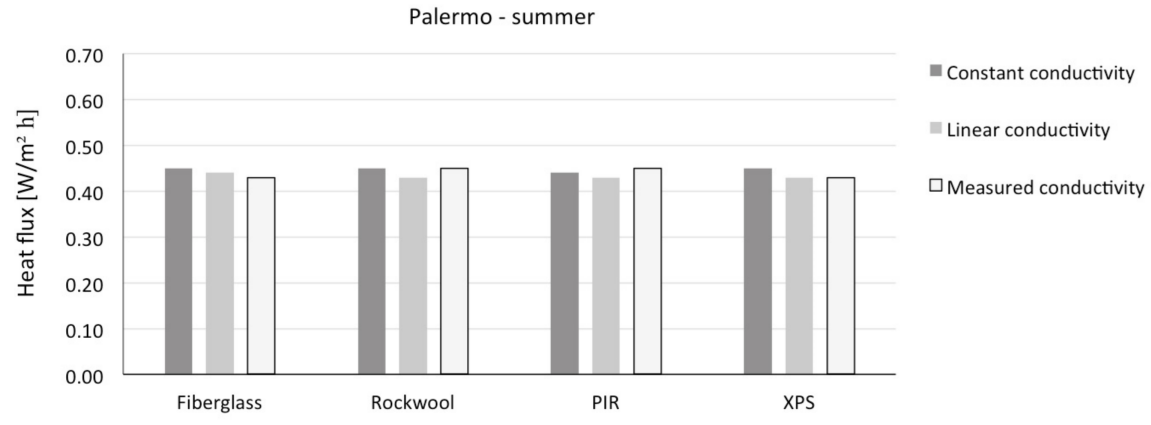

(b)

Figure 7. Heat flux average in exterior walls in Palermo. (a) Palermo-winter; (b) Palermo-summer.

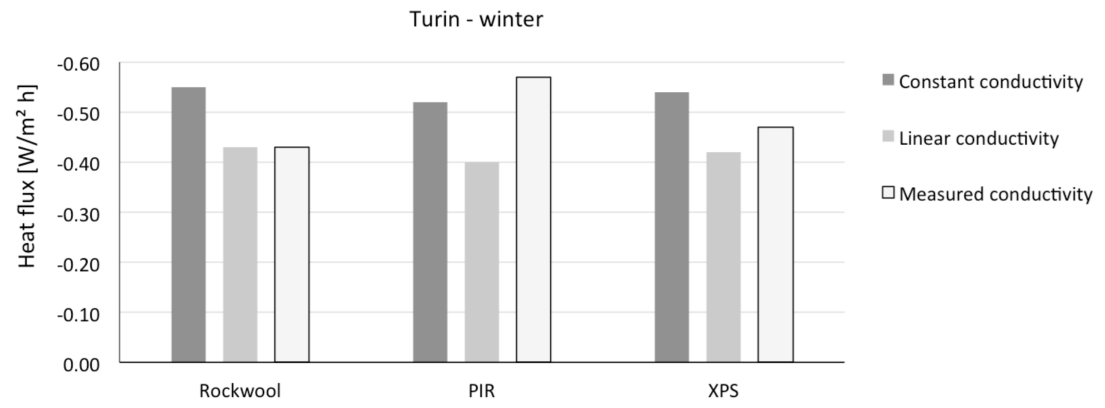

(a)

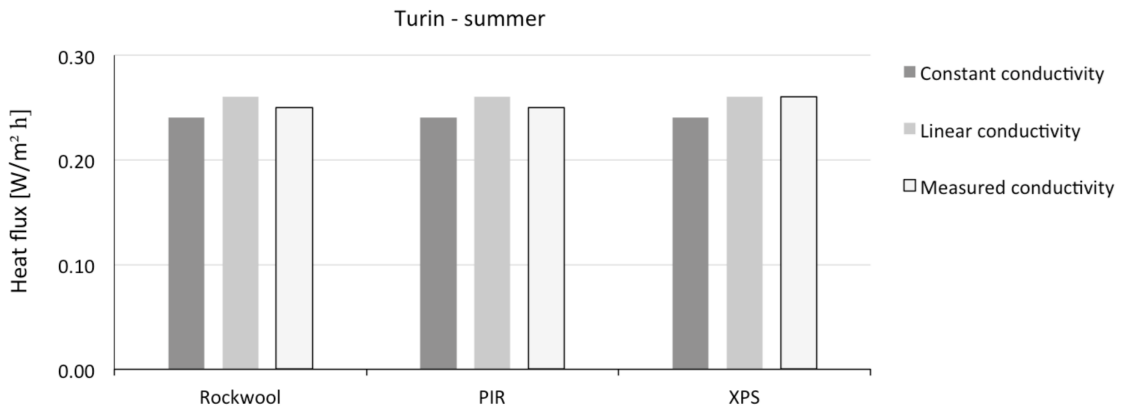

(b)

Figure 8. Heat flux average in flat roofs in Turin. (a) Turin-winter; (b) Turin-summer. 


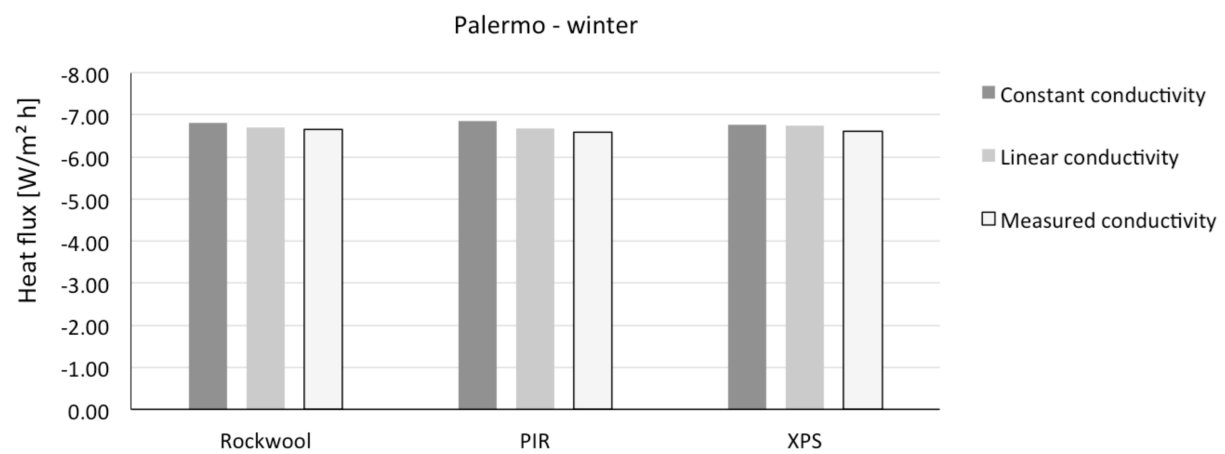

(a)

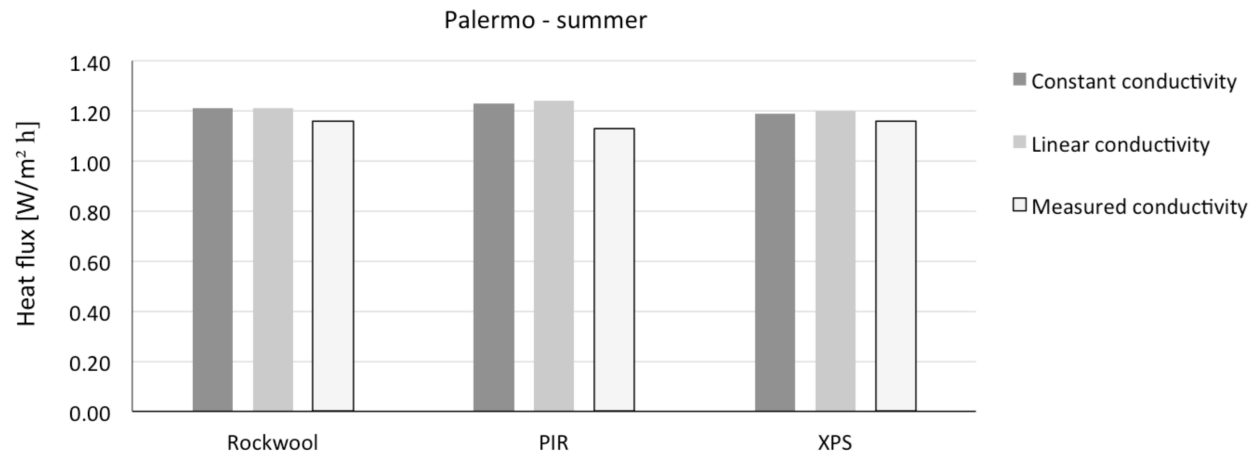

(b)

Figure 9. Heat flux average in flat roofs in Palermo. (a) Palermo-winter; (b) Palermo—summer.

Table 3. Percentage difference of heat flux for exterior walls.

\begin{tabular}{cccccc}
\hline \multirow{2}{*}{ Location } & \multicolumn{5}{c}{ Heat Flux Difference Percentage } \\
& \multirow{2}{*}{ Material } & \multicolumn{2}{c}{ Measured vs. Constant } & \multicolumn{2}{c}{ Measured vs. Linear } \\
\cline { 3 - 6 } & & Winter & Summer & Winter & Summer \\
\cline { 2 - 6 } Turin & Fiberglass & $5.5 \%$ & $0.0 \%$ & $2.1 \%$ & $0.0 \%$ \\
& Rockwool & $1.8 \%$ & $0.0 \%$ & $2.5 \%$ & $2.9 \%$ \\
& PIR & $-2.5 \%$ & $-6.4 \%$ & $-4.6 \%$ & $-9.4 \%$ \\
& XPS & $5.5 \%$ & $3.2 \%$ & $-1.7 \%$ & $3.2 \%$ \\
\hline \multirow{3}{*}{ Rome } & Fiberglass & $-3.2 \%$ & $-3.8 \%$ & $-1.3 \%$ & $-3.8 \%$ \\
& Rockwool & $-0.5 \%$ & $0.0 \%$ & $1.0 \%$ & $0.0 \%$ \\
& PIR & $-1.3 \%$ & $0.0 \%$ & $-1.5 \%$ & $0.0 \%$ \\
& XPS & $1.3 \%$ & $-4.0 \%$ & $-2.5 \%$ & $-7.7 \%$ \\
\hline \multirow{3}{*}{ Palermo } & Fiberglass & $-4.4 \%$ & $-4.4 \%$ & $-1.0 \%$ & $-2.3 \%$ \\
& Rockwool & $0.0 \%$ & $0.0 \%$ & $6.5 \%$ & $4.6 \%$ \\
& PIR & $2.5 \%$ & $2.3 \%$ & $7.7 \%$ & $4.6 \%$ \\
& XPS & $-6.3 \%$ & $-4.4 \%$ & $2.1 \%$ & $0.0 \%$ \\
\hline
\end{tabular}

Highlighted: positive values. 
Table 4. Percentage difference of heat flux for flat roofs.

\begin{tabular}{cccccc}
\hline \multirow{5}{*}{ Location } & \multicolumn{5}{c}{ Heat Flux Difference Percentage } \\
& \multirow{2}{*}{ Material } & \multicolumn{2}{c}{ Measured vs. Constant } & \multicolumn{2}{c}{ Measured vs. Linear } \\
\cline { 3 - 6 } & & Winter & Summer & Winter & Summer \\
\cline { 2 - 6 } Turin & Rockwool & $-21.8 \%$ & $4.2 \%$ & $0.0 \%$ & $-3.8 \%$ \\
& PIR & $9.6 \%$ & $4.2 \%$ & $42.5 \%$ & $-3.8 \%$ \\
& XPS & $-13.0 \%$ & $8.3 \%$ & $12.0 \%$ & $0.0 \%$ \\
\hline \multirow{3}{*}{ Rome } & Rockwool & $-1.9 \%$ & $2.9 \%$ & $10.6 \%$ & $0.0 \%$ \\
& PIR & $-5.1 \%$ & $-2.9 \%$ & $-2.2 \%$ & $-8.1 \%$ \\
& XPS & $-0.5 \%$ & $8.8 \%$ & $2.2 \%$ & $0.0 \%$ \\
\hline \multirow{3}{*}{ Palermo } & Rockwool & $-2.3 \%$ & $-4.1 \%$ & $-0.7 \%$ & $-4.1 \%$ \\
& PIR & $-3.6 \%$ & $-8.1 \%$ & $-1.0 \%$ & $-8.9 \%$ \\
& XPS & $-2.1 \%$ & $-2.5 \%$ & $-1.9 \%$ & $-3.3 \%$ \\
\hline
\end{tabular}

Highlighted: positive values.

A positive value of the percentage difference indicates that the heat flux obtained from simulations with experimentally measured conductivity is higher, in absolute value, than the one obtained with either constant or linear assumptions. This implies that in the winter period an underestimation of heat losses and, consequently, an underestimation of thermal demand for heating flux is negative in all cases. On the other hand, the summer results depend on the sign of the heat flux: when the heat flux is negative, a negative percentage difference implies an underestimation of heat losses (e.g., external walls for Turin) or, vice versa, an underestimation of gains when the heat flux is positive (e.g., external walls for Palermo, horizontal roofs for Turin and Palermo). The differences found by means of simulation remain in most of the cases lower than $10 \%$ in absolute value. The higher values encountered are for polyisocyanurate (PIR) and extruded polystyrene (XPS) in the flat roof in Turin for winter conditions, when comparing linear temperature dependence with respect to measured. The percentage differences in these cases are respectively $42.5 \%$ and $12 \%$. Therefore, we can state that for the cases considered, most of the time a sensitivity analysis assuming constant thermal conductivity would be sufficient to address the issue of accounting for performance variability. This implies the possibility of using conventional simulation tools, although considering a spectrum of input data variability. Clearly, in order to be able to derive general conclusions (e.g., practical indications for sensitivity analyses using conventional stationary and dynamic simulation tools), more extensive experimental and simulation analysis would be necessary, employing statistical reference buildings [48].

\section{Conclusions}

Insulation materials are some of the most crucial elements in energy efficient building design, especially in buildings where heating represents the predominant demand. Standard thermal conductivities assumed in most of the cases in building performance simulations are measured in standard conditions at $23.8^{\circ} \mathrm{C}$. However, a variation of thermal conductivity is clearly to be expected in actual building operation.

The relation between temperature and thermal conductivity can be approximated with a linear function for many materials. For example, inorganic fiber insulations, e.g., rockwool and fiberglass, and some petrochemical-based ones, e.g., extruded polystyrene, are characterized by lower conductivity values at lower temperatures. However, there are materials such as refrigerant blown foam insulation, e.g., polyisocyanurate, that have a nonlinear relation between temperature and conductivity, determined by the condensation of the blowing agent below certain temperatures.

This paper presented experimental analysis of the thermal conductivity of four materials, namely, rockwool, fiberglass, extruded polystyrene, and polyisocyanurate. Temperatures ranging from $-10^{\circ} \mathrm{C}$ to $+50{ }^{\circ} \mathrm{C}$ were used to measure conductivities. The outcomes of laboratory tests were the basis for 
creating thermal conductivity functions (temperature dependent) to represent the behavior within a dynamic thermohygrometric modelling tool, WUFI. By means of this tool, simulations were run for typical construction components such as exterior walls and flat roofs in different Italian climatic conditions, corresponding to the north (Turin), center (Rome), and south (Palermo) of the country.

According to the results obtained, polyisocyanurate determines the larger performance variability with respect to other materials. This becomes more evident in colder climates, as the blowing agent inside the material begins condensing at $10{ }^{\circ} \mathrm{C}$. The research shows how assumptions about thermal conductivity in simulations affect performance estimates. While for Turin the results with measured conductivities implies in many cases a higher simulated thermal demand for heating with respect to constant and linear assumptions, in Rome and in Palermo this effect may not be particularly relevant because of the temperature ranges. In summer conditions, the results depend on the sign of the average heat flux leading to an underestimation of heat losses when the flux is negative or, vice versa, an underestimation of gains when the heat flux is positive. In the last case, the effect may be negative in terms of increased cooling demand or overheating.

This research represents an evaluation of the potential inaccuracies in building performance estimation introduced by assumptions about thermal conductivity of insulation materials. The impact of these inaccuracies when using simulation tools for building design and code compliance checking is relevant because it affects design choices that will influence performance for the whole building life cycle. Further, climate change issues play an important role as well, requiring the designer to consider not only present but also future climate conditions. Finally, at the policy-making level, there should be awareness of the potential faults related to simplified assumptions in the thermohygrometric behavior of construction components and overall building performance.

Acknowledgments: The authors would like to acknowledge Matteo Naldi for the initial analysis on the case study building. The first author wishes to thank the financial support of the Ontario Center for Excellence, Program, the Natural Sciences and Engineering Research Council of Canada (NSERC) and the Ontario Ministry of Research, Innovation and Science.

Author Contributions: Umberto Berardi and Lamberto Tronchin conceived, designed and performed the experiments; Massimiliano Manfren and Benedetto Nastasi analyzed and commented the data; All the Authors equally contributed to write the paper.

Conflicts of Interest: The authors declare no conflict of interest.

\section{References}

1. Berardi, U. A cross-country comparison of the building energy consumptions and their trends. Resour. Conserv. Recycl. 2017, 123, 230-241. [CrossRef]

2. Europa. Directive 2002/91/EC of the European Parliament and of the Council of 16 December 2002 on the Energy Performance of Buildings; Europa: Brussels, Belgium, 2003.

3. Europa. Directive 2010/31/EU of the European Parliament and of the Council of 19 May 2010 on the Energy Performance of Buildings (EPBD Recast); Europa: Brussels, Belgium, 2010.

4. Europa. Directive 2012/27/EU of the European Parliament and of the Counci of 25 October 2012 on Energy Efficiency; Europa: Brussels, Belgium, 2012.

5. Buildings Performance Institute Europe (BPIE). Europe's Buildings under the Microscope; BPIE: Brussels, Belgium, 2011.

6. Saheb, Y.; Bodis, K.; Szabo, S.; Ossenbrink, H.; Panev, S. Energy Renovation: The Trump Card for the New Start for Europe; JRC EU Commission: Brussels, Belgium, 2015.

7. Energy Efficiency Financial Institutions Group (EEFIG). Energy Efficiency-The First Fuel for the EU Economy, How to Drive New Finance for Energy Efficiency Investments. 2015. Available online: https:/ / www.db.com/cr/en/concrete-EEFIG-report--Energy-Efficiency-the-first-fuel-for-the-EUEconomy.htm (accessed on 7 April 2018).

8. Asdrubali, F.; D'Alessandro, F.; Schiavoni, S. A review of unconventional sustainable building insulation materials. Sustain. Mater. Technol. 2015, 4, 1-17. [CrossRef] 
9. Noussan, M.; Nastasi, B. Data Analysis of Heating Systems for Buildings-A Tool for Energy Planning, Policies and Systems Simulation. Energies 2018, 11, 233. [CrossRef]

10. Aste, N.; Buzzetti, M.; Caputo, P.; Manfren, M. Local energy efficiency programs: A monitoring methodology for heating systems. Sustain. Cities Soc. 2014, 13, 69-77. [CrossRef]

11. Papadopoulos, A.M. State of the art in thermal insulation materials and aims for future developments. Energy Build. 2005, 37, 77-86. [CrossRef]

12. Lo Basso, G.; Nastasi, B.; Salata, F.; Golasi, I. Energy retrofitting of residential buildings-How to couple Combined Heat and Power (CHP) and Heat Pump (HP) for thermal management and off-design operation. Energy Build. 2017, 151, 293-305. [CrossRef]

13. Tronchin, L.; Tommasino, M.C.; Fabbri, K. On the "cost-optimal levels" of energy performance requirements and its economic evaluation in Italy. Int. J. Sustain. Energy Plan. Manag. 2014, 3. [CrossRef]

14. Aste, N.; Adhikari, R.S.; Manfren, M. Cost optimal analysis of heat pump technology adoption in residential reference buildings. Renew. Energy 2013, 60, 615-624. [CrossRef]

15. EU Project ENTRANZE. Available online: http://www.entranze.eu/pub/pub-optimality (accessed on 7 February 2018).

16. Kaynakli, O. A review of the economical and optimum thermal insulation thickness for building applications. Renew. Sustain. Energy Rev. 2012, 16, 415-425. [CrossRef]

17. Kotireddy, R.; Hoes, P.-J.; Hensen, J.L.M. A methodology for performance robustness assessment of low-energy buildings using scenario analysis. Appl. Energy 2018, 212, 428-442. [CrossRef]

18. Imam, S.; Coley, D.A.; Walker, I. The building performance gap: Are modellers literate? Build. Serv. Eng. Res. Technol. 2017, 38, 351-375. [CrossRef]

19. Herring, H.; Roy, R. Technological innovation, energy efficient design and the rebound effect. Technovation 2007, 27, 194-203. [CrossRef]

20. Sunikka-Blank, M.; Galvin, R. Introducing the prebound effect: The gap between performance and actual energy consumption. Build. Res. Inf. 2012, 40, 260-273. [CrossRef]

21. Taylor, J.; Davies, M.; Mavrogianni, A.; Chalabi, Z.; Biddulph, P.; Oikonomou, E.; Das, P.; Jones, B. The relative importance of input weather data for indoor overheating risk assessment in dwellings. Build. Environ. 2014, 76, 81-91. [CrossRef]

22. Ligier, S.; Robillart, M.; Schalbart, P.; Peuportier, B. Energy performance contracting methodology based upon simulation and measurement. In Proceedings of the Building Simulation 2017, San Francisco, CA, USA, 7-9 August 2017.

23. Wufi Software. Available online: https://wufi.de/en/ (accessed on 7 February 2018).

24. Ente Nazionale Italiano di Unificazione-ISO. Hygrothermal Performance of Building Components and Building Elements-Internal Surface Temperature to Avoid Critical Surface Humidity and Interstitial Condensation -Calculation Methods; UNI EN ISO 13788; UNI: Milan, Italy, 2008.

25. Pfundstein, M.; Gellert, R.; Spitzner, M.; Rudolphi, A. Insulating Materials: Principles, Materials, Applications; Walter de Gruyter: Berlin, Germany, 2008.

26. Ente Nazionale Italiano di Unificazione-ISO. Energy Performance of Buildings_Calculation of Energy Use for Space Heating and Cooling; UNI EN ISO 13790; UNI: Milan, Italy, 2008.

27. International Organization for Standardization (ISO). Energy Performance of Buildings-Overarching EPB Assessment-Part 1: General Framework and Procedures (Draft); ISO/DIS 52000-1; ISO: Geneva, Switzerland, 2007.

28. Ente Nazionale Italiano di Unificazione-ISO. Building Components and Building Elements-Thermal Resistance and Thermal Transmittance-Calculation Method; UNI EN ISO 6946; UNI: Milan, Italy, 2008.

29. Ente Nazionale Italiano di Unificazione-ISO. Energy Performance of Buildings_Transmission and Ventilation Heat Transfer Coefficients_Calculation Method; UNI EN ISO 13789; UNI: Milan, Italy, 2008.

30. Capozzoli, A.; Gorrino, A.; Corrado, V. A building thermal bridges sensitivity analysis. Appl. Energy 2013, 107, 229-243. [CrossRef]

31. Ente Nazionale Italiano di Unificazione-ISO. Thermal Performance of Building Components—Dynamic Thermal Characteristics—Calculation Methods; UNI EN ISO 13786; UNI: Milan, Italy, 2008.

32. Karlsson, J.; Wadsö, L.; Öberg, M. A conceptual model that simulates the influence of thermal inertia in building structures. Energy Build. 2013, 60, 146-151. [CrossRef] 
33. Martin, K.; Erkoreka, A.; Flores, I.; Odriozola, M.; Sala, J.M. Problems in the calculation of thermal bridges in dynamic conditions. Energy Build. 2011, 43, 529-535. [CrossRef]

34. Mantesi, E.; Hopfe, C.J.; Cook, M.J.; Glass, J.; Strachan, P. The modelling gap: Quantifying the discrepancy in the representation of thermal mass in building simulation. Build. Environ. 2018, 131, 74-98. [CrossRef]

35. Aste, N.; Leonforte, F.; Manfren, M.; Mazzon, M. Thermal inertia and energy efficiency-Parametric simulation assessment on a calibrated case study. Appl. Energy 2015, 145, 111-123. [CrossRef]

36. Tronchin, L.; Manfren, M.; Tagliabue, L.C. Optimization of building energy performance by means of multi-scale analysis-Lessons learned from case studies. Sustain. Cities Soc. 2016, 27, 296-306. [CrossRef]

37. Lepage, R.; Schumacher, C.; Straube, J.; Luxachko, A. The Implications of Temperature Dependent Thermal Conductivity of Exterior Wall Using Insulated Sheathing; Building Science Consulting: Waterloo, ON, Canada, 2013.

38. Al-Homoud, D.M.S. Performance characteristics and practical applications of common building thermal insulation materials. Build. Environ. 2005, 40, 353-366. [CrossRef]

39. Budaiwi, I.; Abdou, A.; Al-Homoud, M. Variations of thermal conductivity of insulation materials under different operating temperatures: Impact on envelope-induced cooling load. J. Archit. Eng. 2002, 8, 125-132. [CrossRef]

40. Budaiwi, I.; Abdou, A. The impact of thermal conductivity change of moist fibrous insulation on energy performance of buildings under hot-humid conditions. Energy Build. 2013, 60, 388-399. [CrossRef]

41. Cuce, E.; Cuce, P.M.; Wood, C.J.; Riffat, S.B. Toward aerogel based thermal superinsulation in buildings: A comprehensive review. Renew. Sustain. Energy Rev. 2014, 34, 273-299. [CrossRef]

42. Arnfield, A.J. Köppen Climate Classification. 2016. Available online: https://www.britannica.com/science/ Koppen-climate-classification (accessed on 7 February 2018).

43. Kontoleon, K.J.; Giarma, C. Dynamic thermal response of building material layers in aspect of their moisture content. Appl. Energy 2016, 170, 76-91. [CrossRef]

44. Berardi, U.; Naldi, M. The impact of the temperature dependent thermal conductivity of insulating materials on the effective building envelope performance. Energy Build. 2017, 144, 262-275. [CrossRef]

45. Jentsch, M.F.; Bahaj, A.S.; James, P.A.B. Climate change future proofing of buildings—Generation and assessment of building simulation weather files. Energy Build. 2008, 40, 2148-2168. [CrossRef]

46. Jentsch, M.F.; James, P.A.B.; Bourikas, L.; Bahaj, A.S. Transforming existing weather data for worldwide locations to enable energy and building performance simulation under future climates. Renew. Energy 2013, 55, 514-524. [CrossRef]

47. Noussan, M.; Jarre, M. Multicarrier energy systems: Optimization model based on real data and application to a case study. Int. J. Energy Res. 2018, 42, 1338-1351. [CrossRef]

48. Corgnati, S.P.; Fabrizio, E.; Filippi, M.; Monetti, V. Reference buildings for cost optimal analysis: Method of definition and application. Appl. Energy 2013, 102, 983-993. [CrossRef] 